\title{
Topographic characterization of cp-Ti implants with machined and modified surface
}

\section{by LASER}

\section{Caracterização topográfica de implantes Ti- cp com superfície usinada e modificada por LASER \\ Caracterización topográfica de implantes Ti- cp con superficie mecanizada y modificada por}

\section{LASER}

Received: 01/20/2021 | Reviewed: 01/30/2021 | Accept: 03/02/2021 | Published: 02/09/2021

Ana Flávia Piquera Santos ORCID: https://orcid.org/0000-0001-7562-772X

São Paulo State University, Brazil

E-mail: anaflaviaps_06@hotmail.com

Henrique Hadad

ORCID: https://orcid.org/0000-0001-6446-3643

São Paulo State University, Brazil

E-mail: henriquehadad@gmail.com

Lais Kawamata De Jesus

ORCID: https://orcid.org/0000-0002-0459-5860

São Paulo State University, Brazil

E-mail: kawamata_lais@hotmail.com

Rodrigo Capalbo Da Silva

ORCID: https://orcid.org/0000-0003-0245-0104

São Paulo State University, Brazil

E-mail: capalbo.rodrigo@gmail.com

Luara Teixeira Colombo

ORCID: https://orcid.org/0000-0001-6261-6044

São Paulo State University, Brazil

E-mail: luara_colombo@hotmail.com

Antônio Carlos Guastaldi

ORCID: https://orcid.org/0000-0002-6433-3555

São Paulo State University, Brazil

E-mail: ac.guastaldi@unesp.br

Thallita Pereira Queiroz

ORCID: https://orcid.org/0000-0002-2464-8181

University of Araraquara, Brazil

E-mail: thaqueiroz@hotmail.com

Roberta Okamoto

ORCID: https://orcid.org/0000-0002-6773-6966

São Paulo State University, Brazil

E-mail: beta.okamoto@gmail.com

Idelmo Rangel Garcia-Júnior

ORCID: https://orcid.org/0000-0001-8892-781X

São Paulo State University, Brazil

E-mail: irgcirurgia@gmail.com

Celso Koogi Sonoda

ORCID: https://orcid.org/0000-0001-8639-1767

São Paulo State University, Brazil

E-mail: celso.k.sonoda@ unesp.br

Pier Paolo Poli

ORCID: https://orcid.org/0000-0003-3739-1490 University of Milan, Italy

E-mail: pierpaolo.poli@unimi.it

Francisley Ávila Souza

ORCID: https://orcid.org/0000-0002-1427-071X

São Paulo State University, Brazil

E-mail: francisley.avila@unesp.br

\begin{abstract}
This study characterized the topography osseointegrated implants (cp-Ti) with machined surface (MS), laser beam surface (LS) and laser beam surface followed by deposition of sodium silicate (SS) by means SEM-EDX, roughness measurements, cross-sectional roughness, contact angle, X-ray diffraction (XRD) and laser confocal optical perfilometry. The SEM of MS showed smooth surface, contaminated with machining residues, while LS and SS rough
\end{abstract}


surfaces with a more regular and homogeneous morphological pattern. The EDX showed Ti peaks for MS and Ti and oxygen for LS and SS. The mean roughness values of LS and SS were statistically higher $(\mathrm{p}<0.05)$ than MS. The contact angle of LS and SS was $0^{\circ}$. The XRD of MS showed only Ti peaks, while LS and SS showed the presence of oxides and nitrides and presence of sodium silicate. The surface treatment performed in the LS and SS promoted important modifications in the topography and physical-chemical properties.

Keywords: Microscopy electron scanning; Dental implants; Topography; Laser beam.

\section{Resumo}

Este estudo caracterizou a topografia dos implantes osseointegrados (Ti-cp) com superfície usinada (MS), superfície do feixe de laser (LS) e superfície do feixe de laser seguida de deposição de silicato de sódio (SS) por meio MEVEDX, medidas de rugosidade, transversal rugosidade, ângulo de contato, difração de raios X (DRX) e perfilometria óptica confocal a laser. O MEV de MS apresentou superfície lisa, contaminada com resíduos de usinagem, enquanto LS e SS rugosidades com padrão morfológico mais regular e homogêneo. O EDX mostrou picos de Ti para MS e Ti e oxigênio para LS e SS. Os valores médios de rugosidade de LS e SS foram estatisticamente maiores $(\mathrm{p}<0,05)$ do que MS. O ângulo de contato de LS e SS era de $0^{\circ}$. O DRX de MS apresentou apenas picos de Ti, enquanto LS e SS mostraram a presença de óxidos e nitretos e presença de silicato de sódio. O tratamento superficial realizado no LS e SS promoveu modificações importantes na topografia e nas propriedades físico-químicas.

Palavras-chave: Microscopia eletrônica de varredura; Implantes dentários; Topografia; Feixe de laser.

\section{Resumen}

Este estudio caracterizó la topografía de implantes osteointegrados (Ti-cp) con superficie mecanizada (MS), superficie de rayo láser (LS) y superficie de rayo láser seguida de deposición de silicato de sodio (SS) mediante MER-EDX, medidas de rugosidad, corte transversal rugosidad, ángulo de contacto, difracción de rayos X (DRX) y perfilometría óptica confocal láser. El MER de MS mostró superficie lisa, contaminada con residuos de mecanizado, mientras que LS y SS superficies rugosas con un patrón morfológico más regular y homogéneo. El EDX mostró picos de Ti para MS y Ti y oxígeno para LS y SS. Los valores medios de rugosidad de LS y SS fueron estadísticamente más altos (p $<0.05)$ que MS. El ángulo de contacto de LS y SS fue $0^{\circ}$. La DRX de MS mostró solo picos de Ti, mientras que LS y SS mostraron la presencia de óxidos y nitruros y presencia de silicato de sodio. El tratamiento superficial realizado en LS y SS promovió importantes modificaciones en la topografía y propiedades físico-químicas.

Palabras clave: Microscopía Electrónica de Rastreo; Implantes dentales; Topografía; Rayo láser.

\section{Introduction}

The concept of osseointegration was defined as the structural, direct and functional connection between the organized and healthy bone and the implant surface at an optical microscopic level, capable of withstanding masticatory forces (Bränemark, et al., 1983). In order to provide better repair around osseointegrated implants, several measures have been suggested over the past few years. These measurements have almost always been related to the surface characteristics (Shibli, et al., 2007), more precisely in the topographic properties of the material (Albrektsson \& Wennerberg, 2004). Previous studies have demonstrated that the surface treatment has allowed higher removal values by reverse torque (Carlsson, et al., 1988; Kesser-Liechti, et al., 2008; Faeda, et al., 2009) and bone / implant contact (Thomas \& Cook, 1992; Xavier, et al., 2003; Qahash, et al., 2007), when compared to machined surface implants.

New methods of surface modification have been studied with promising results. Among these, the surface modification by laser beam stands out, which has the advantage of clean processing with a high degree of purity, in addition to being executed in a controlled and reproducible way (Carlsson, et al., 1988; Gaggl, et al.,2000; Cho \& Jung, 2003; Braga, et al., 2007; Faeda, et al., 2009; Faeda, et al., 2009; Queiroz, et al., 2013; Sisti, et al., 2013; Souza, et al., 2013). The most common types of lasers used in material studies are those generated by a mixture of gases containing carbon dioxide (CO2) and the Yb: YAG laser (ytterbium laser). Currently, there is a trend towards the use of the ytterbium laser due to the advantage of being transported by flexible optical fibers, the absorption of the larger laser by the metal, wavelength and power of $20 \mathrm{~W}$ (Gaggl, et al., 2000). This type of laser has sufficient and adequate energy to modify the implant surface (Carlsson, et al., 1988; Gaggl, et al., 2000; Queiroz, et al., 2013; Sisti, et al., 2013; Souza, et al., 2013), and higher values for removal by reverse torque (Cho \& Jung, 2003; Faeda, et al., 2009; Sisti, et al., 2013). Previous published studies have shown that the modification 
of the ytterbium laser surface provides greater bone / implant contact (Cho \& Jung, 2003; Faeda, et al., 2009; Sisti, et al., 2013) when compared to the machined surface.

The deposition of biomaterials on a previously modified surface has been the subject of recent researches. The objective is to make the surface bioactive and osteocondutor. The surface modification technique by laser beam associated with sodium silicate deposition showed promising results in a previous published study (Souza, et al., 2013; Souza, et al., 2014). Sodium silicate is similar to silica oxide, found in the composition of bioactive ceramics. This compound acts as an osteoconductor by stimulating the differentiation of undifferentiated mesenchymal cells in osteoblasts, thus favoring the migration of osteogenic cells to the fibrin network promoted by the blood clot (Souza, et al., 2014).

In view of the above, the objective of this study was to characterize the topography of osseointegrated implants (cpTi) with machined surface (MS), laser modified surface (LS) and laser modified surface followed by deposition of sodium silicate (SS), using scanning electron microscopy (SEM-EDX), mean roughness measurements, cross-section roughness measurements, contact angle, X-ray diffraction (XRD) and confocal laser optical perfilometry.

\section{Methodology}

The methodology applied in this study followed the guidelines described in Pereira (2018).

\section{Surfaces}

In this study, implants of commercially pure titanium (cp-Ti), grade IV with external hexagon connection, and dimensions of 3.75x10mm (Conexão Sistemas de Prótese, São Paulo, Brazil) were used with 3 different types of surfaces. Titanium disks with dimensions of $14 \mathrm{~mm}$ in diameter and $3 \mathrm{~mm}$ in thickness were also manufactured by the same company that supplied the implants. The analyzed surfaces were the machined and 2 experimental surfaces that were modified by the Biomaterials Group of the São Paulo State University (UNESP), Institute of Chemistry, Araraquara. The analyzed surfaces were:

$(M S)$ - Machined surface;

$(L S)$ - Surface modified by laser beam;

(SS) - Surface modified by laser beam followed by deposition of sodium silicate.

\section{Preparation of experimental surfaces}

\section{Surface modified by laser beam (LS)}

The cp-Ti implants with machined surface were fixed in a rotary lathe under the pulsed $\mathrm{Yb}$ : $20 \mathrm{~W}$ laser equipment (Pulsed Ytterbium Fiber Laser, OmniMark System 20F, Ominitek Tecnologia Ltda, São Paulo, Brazil), with parameters of $140 \mathrm{~mJ}$ nominal power supply and pulse frequency of $20 \mathrm{KHz}$. The laser beam was designed over the entire surface of the spiral implants at room temperature.

\section{Surface modified by laser beam followed by deposition of sodium silicate (SS)}

After irradiation of the surface by laser beam, the samples were immersed in $50 \mathrm{~mL}$ of $\mathrm{NaOH}$ solution (5.0 Mol.L-1) in the greenhouse for a period of 24 hours at $60^{\circ} \mathrm{C}$, for the activation of the surface, forming a layer of sodium titanate. After immersion in alkaline solution, the samples were kept in the oven for 3 hours. The samples were then immersed in $70 \mathrm{ml}$ of a sodium silicate solution, pH 7.25 and kept in the oven for 24 hours at $37^{\circ} \mathrm{C}$ (Souza, et al., 2013). 


\section{Topography characterization of surfaces}

\section{Scanning electron microscopy analysis coupled to the X-ray dispersive energy spectrometry system - SEM-EDX}

The topography of the surface of the samples was analyzed using a scanning electron microscope (SEME ZEISS, model EVO LS15, equipped with an EDX microanalysis detector of the Inca X-act model, Oxford), coupled with the dispersive energy spectrometry X-ray (EDX), for semi-quantitative analysis of the chemical composition of surfaces (Queiroz, et al., 2013; Souza, et al., 2013; Souza, et al., 2014; Queiroz, et al., 2017).

\section{Average rugosimetry}

The average roughness $(\mathrm{Ra})$ was analyzed in previously prepared discs of each surface by means of a rugosimeter (Mitutoyo SJ-400, Mitutoyo Sul Americana Ltda, São Paulo, Brazil). The results were submitted to statistical analysis of variance and Tukey's t-test (p <0.05) (Queiroz, et al., 2013; Souza, et al., 2013; Souza, et al., 2014; Queiroz, et al., 2017)

\section{Roughness in cross section}

Cp-Ti discs were analyzed in cross-section by SEM to determine the roughness thickness. Ten cross-sectional measurements of the experimental surfaces were performed. The values were annotated and tabulated. The average roughness of each surface was obtained. For the machined surface it was not possible to do this analysis, because there is no topographic modification of the surface (Queiroz, et al., 2013; Souza, et al., 2013; Souza, et al., 2014).

\section{Contact angle measurements}

The wettability of the samples (disks) was measured at room temperature with 75\% relative humidity, using a Contact Angle System (video-based Dataphysics, model OCA-15) for contact angle analysis. The measurement of each sample was repeated 3 times to obtain the mean value of the contact angle $(\theta)$ of the different surfaces (Queiroz, et al., 2013).

\section{$X$-ray diffractometry - XRD}

The crystalline composition, as well as the types and phases of oxides formed for the modified surfaces, were analyzed by X-ray diffractometry (XRD) using an X-ray diffractometer (SIEMENS D5000 with angular sweep between 4 and $\left.70^{\circ}\right)$ (Queiroz, et al., 2013).

\section{Laser confocal optical perfilometry}

The roughness pattern of the samples was also analyzed by a confocal microscope, in which the light source consists of several laser beams that act as a scanner, focusing the sample line by line. The sample was then read by other detectors at a different wavelength, obtaining the peer-to-peer image through software. In addition, this microscope was able to form threedimensional images through the union of two-dimensional images obtained by optical sectioning.

\section{Results}

\section{Scanning electron microscopy analysis coupled to the X-ray dispersive energy spectrometry system - SEM/EDX}

Scanning electron microscopy of the surfaces analyzed showed topographic differences between them. The MS presented a smooth surface topography, contaminated with machining debris (Fig.1a, b, c), while LS (Fig. 2a, b, c), and SS (Fig.3a, b, c) produced rough surfaces with a more regular and homogeneous morphological pattern. 
EDX analysis revealed no contamination of the surfaces analyzed, and showed peaks of titanium for MS (Fig.1d). For the LS, titanium and oxygen peaks were observed (Fig.2d). However, SS revealed the presence of titanium, oxygen, silica, chlorine and sodium peaks (Fig.3d).

Figure 1. (a, b, c) SEM: MS (500X, 1000X and 5000X), (d) MS EDX.

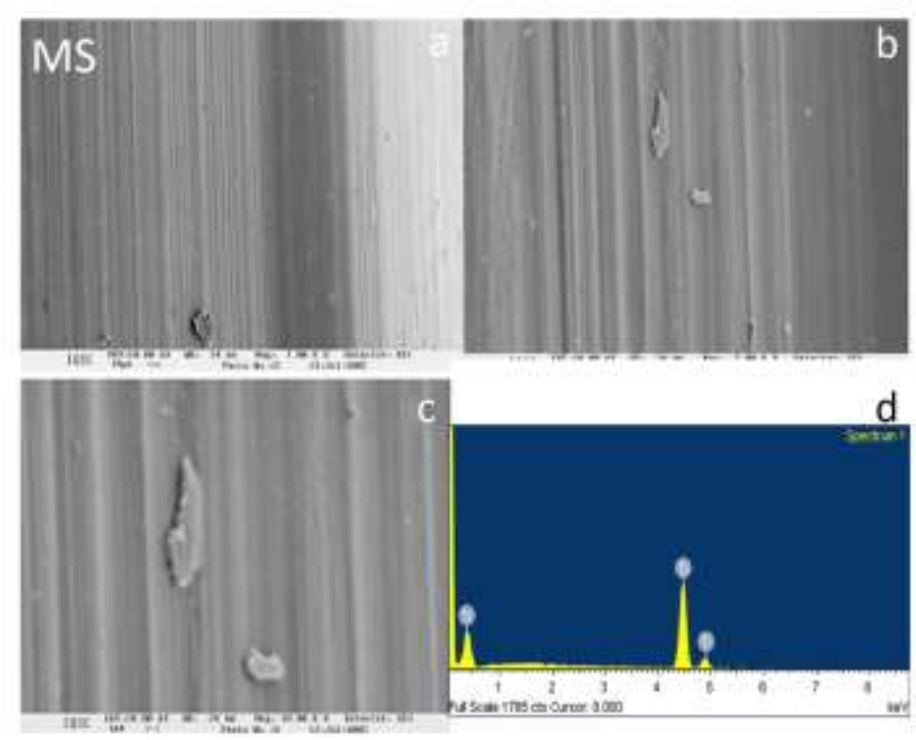

Source: Authors.

Figure 2. (a, b, c) SEM: LS (1000X, 5000X and 10000X), (d) LS EDX.

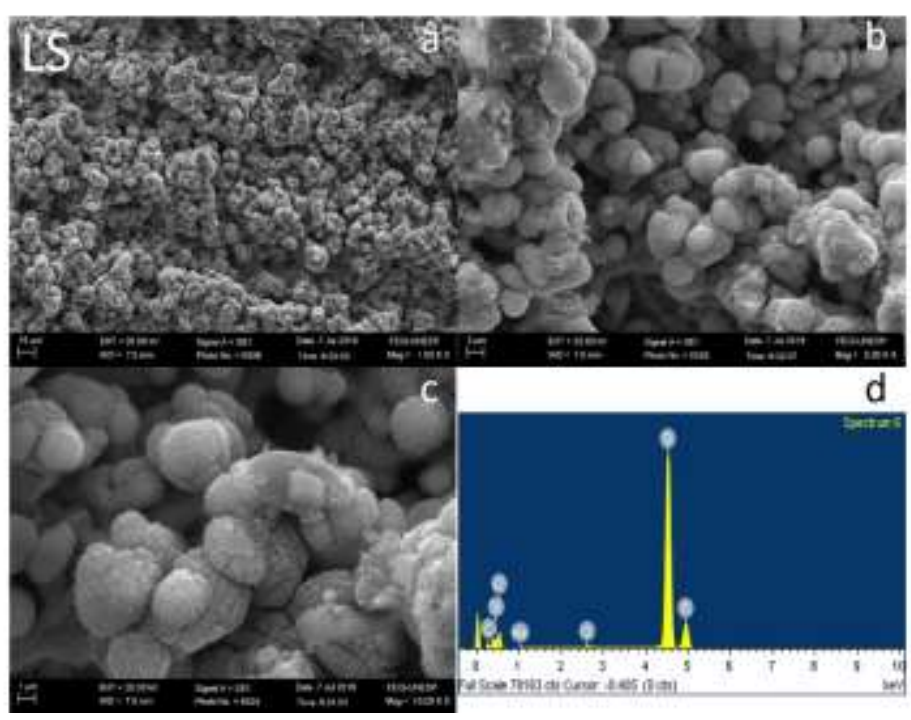

Fonte: Autores. 
Figure 3. (a, b, c) SEM: SS (1000X, 5000X and 10000X), (d) SS EDX.

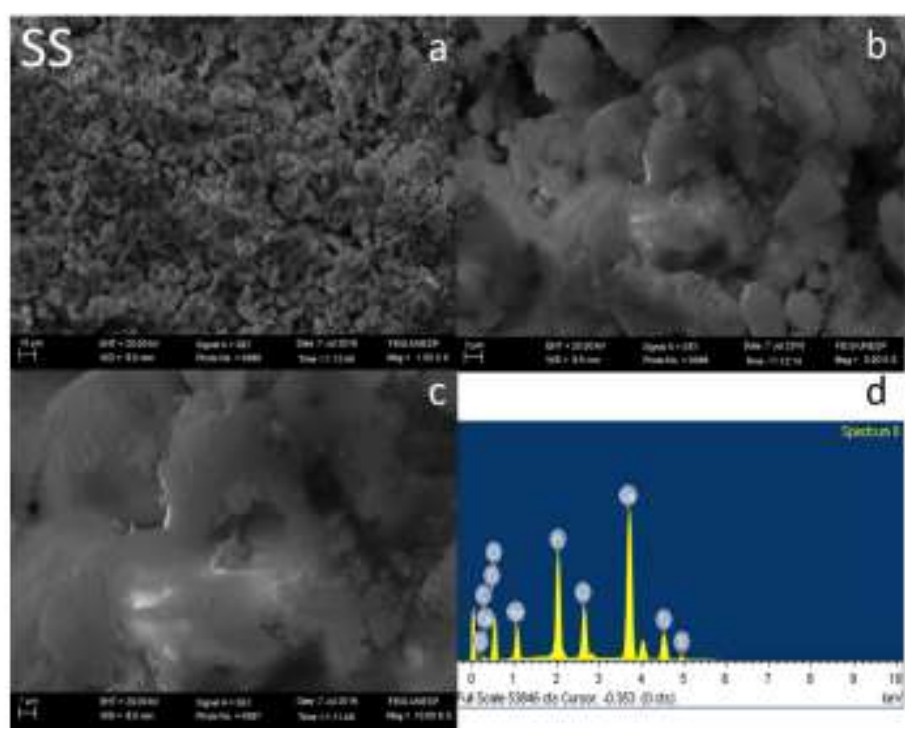

Source: Authors.

\section{Average rugosimetry}

The average roughness MS was $0.4 \pm 0.06 \mu \mathrm{m}$, while LS was $4.73 \pm 0.48 \mu \mathrm{m}$ and SS $5.12 \pm 0.32 \mu \mathrm{m}$ (Table 1). The microtopographic analysis revealed a statistically significant difference $(\mathrm{p}<0.05)$ between the analyzed surfaces. The surface roughness of SS and LS were statistically superior when compared to the MS.

Table 1. Mean and standard deviation of different surface.

MS LS LS

\begin{tabular}{l|l|l}
\hline $0.4 \pm 0.06 \mu \mathrm{m}(\mathrm{a})$ & $4.73 \pm 0.48 \mu \mathrm{m}(\mathrm{b})$ & $5.12 \pm 0.32 \mu \mathrm{m}(\mathrm{b})$
\end{tabular}

Different letters indicate statistical difference between the roughness surfaces. Source: Authors

\section{Roughness measures in cross section}

SEM in cross section made on MS surface showed smooth surface due to absence of surface treatment (Fig.4a). The cross section of the discs showed a mean thickness of $0.84 \pm 0.3 \mu \mathrm{m}$ for MS (Fig.4a), $21.76 \pm 9.05 \mu \mathrm{m}$ for LS (Fig.4b) and $28.75 \pm 10.12 \mu \mathrm{m}$ for SS (Fig.4c). SEM in cross-section of the surface (SS) showed the presence of a "hybrid" layer, composed by irradiation with laser beam followed by deposition of sodium silicate, it being impossible to distinguish the laser beam modification of the silicate deposit sodium. 
Figure 4. Mean Disk Thickness (a) MS (0.84 $\pm 0.3 \mu \mathrm{m})$, (b) LS $(21.76 \pm 9.05 \mu \mathrm{m})$, (c) SS $(28.75 \pm 10.12 \mu \mathrm{m})$.
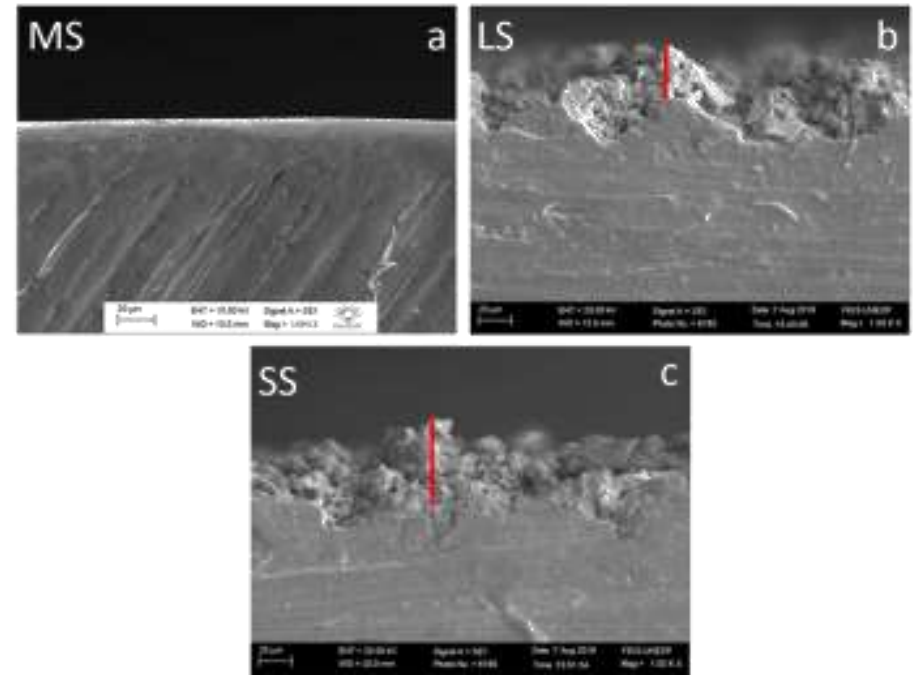

Source: Authors.

\section{Contact angle measurements}

The contact angles obtained for the analyzed surfaces are shown in Table 2. It was found that the MS surface did not show adequate wetting, considering that the average contact angle of the surface was high $\left(74.3^{\circ}\right)$.

Table 2. Contact Angle Obtained for Different Surfaces.

\begin{tabular}{|l|l|l|l|l|}
\hline Surface/Angle & 1st evaluation & 2st evaluation & 3st evaluation & Mean \\
\hline LS & 0 & 0 & 0 & 0 \\
\hline SS & 0 & 0 & 0 & 0 \\
\hline MS & $68.9^{\circ}$ & $81.2^{\circ}$ & $72.9^{\circ}$ & $74.3^{\circ}$ \\
\hline
\end{tabular}

Source: Authors.

\section{$X$-ray diffractometry - XRD}

The XRD of MS showed only titanium peaks (Fig.5a), while LS showed the presence of oxides and nitrides (TiN) (Fig.5b) from the interaction between the surface and the air during the laser ablation process on the surface of the implant. XRD of SS revealed silica peaks (Fig.5c), characteristic of crystallinity, probably obtained during the deposition of sodium silicate. 
Figure 5. ray diffractometry of differents surfaces: (a) MS, (b) LS, (c) SS.

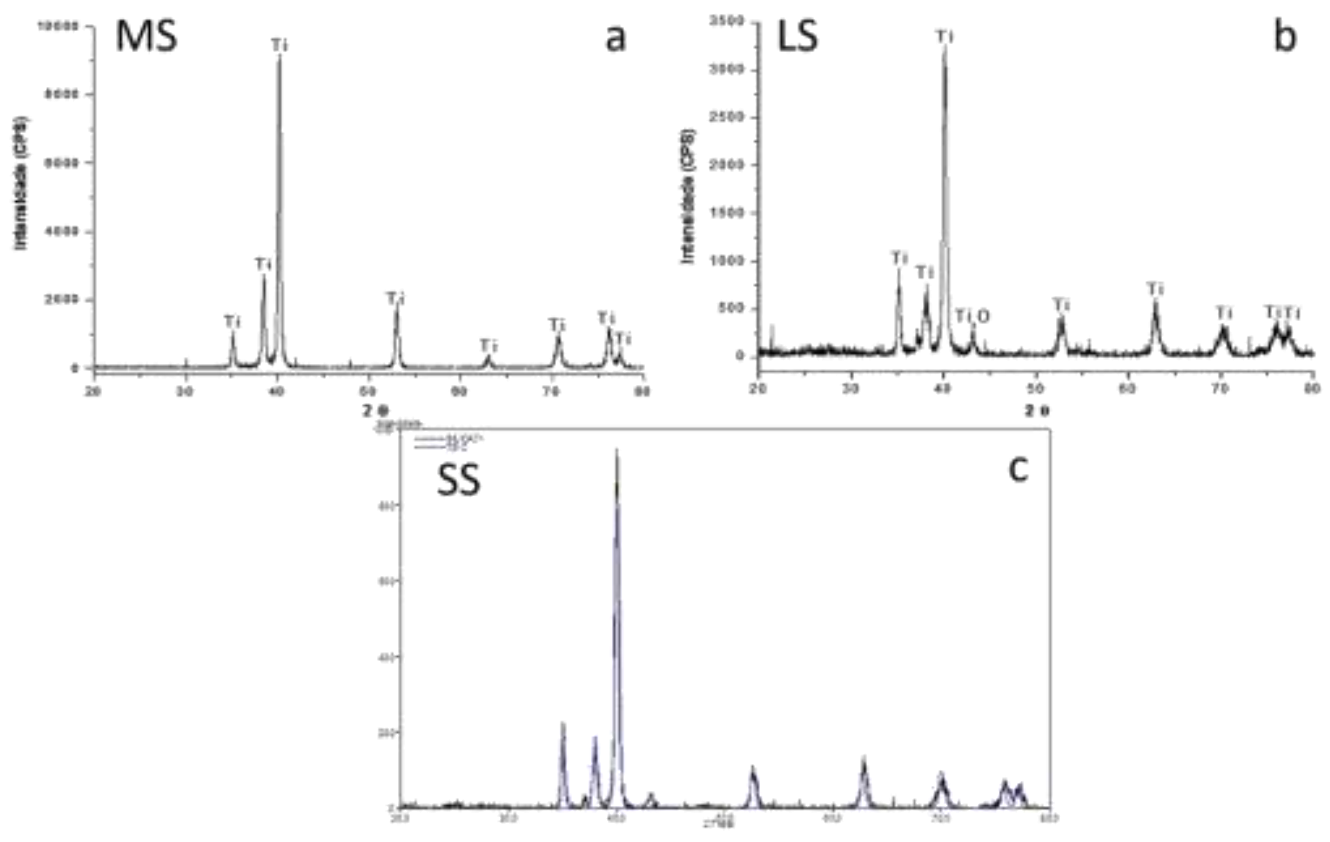

Source: Authors.

\section{Laser confocal optical perfilometry}

The confocal microscopy of MS showed a smoother surface with typical machining signals (Fig.6b, c) and it was observed in the 3D image (Fig.6a) that there were no peaks or valleys, being a smooth surface with "grooves" caused by the machining process. In the LS analysis, a homogeneous rough surface was evidenced with greater thickness when compared to the MS surface (Fig.7b, c). The 3D image of LS shows the peaks and valleys with a well-defined similar to honeycombs and homogeneous morphological pattern (Fig.7a). In the SS analysis confocal microscopy showed a rough surface, similar to the LS surface, with homogeneous pattern and greater thickness (Fig.8b, c) and in the 3D image it can be noticed that there were peaks and valleys similar to honeycombs, but some areas showed higher peaks due to the deposition of the sodium silicate (Fig.8a). The mean roughness values obtained in the profile analysis were $0.5247 \mu \mathrm{m}, 8.2754 \mu \mathrm{m}$ and $5.7120 \mu \mathrm{m}$ for MS, LS and SS respectively. 
Research, Society and Development, v. 10, n. 2, e15910212217, 2021

(CC BY 4.0) | ISSN 2525-3409 | DOI: http://dx.doi.org/10.33448/rsd-v10i2.12217

Figure 6. (a b c) Confocal Optical Perfilometry Laser MS - 20x.
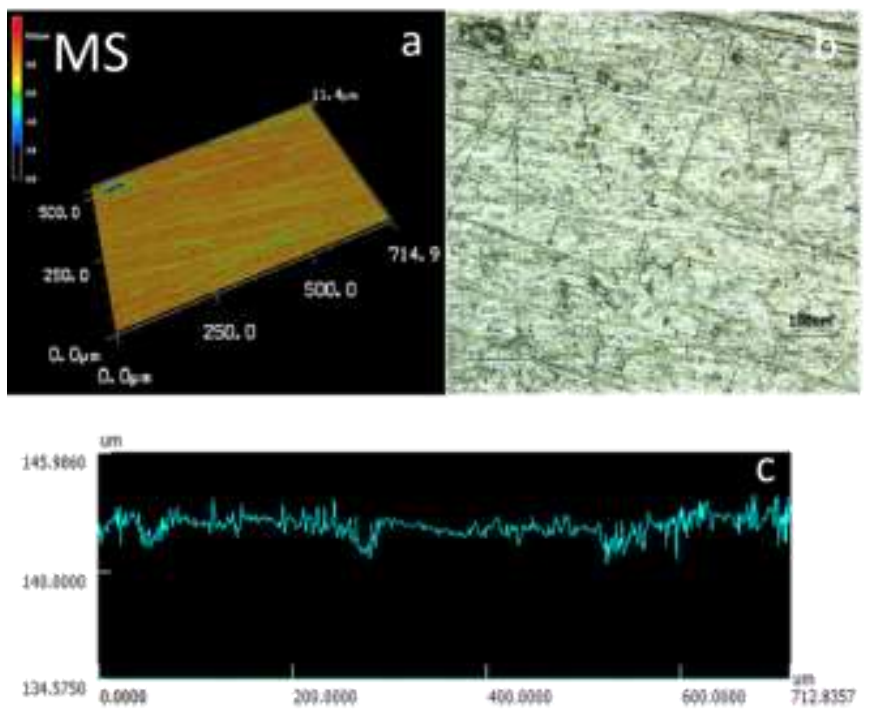

Source: Authors.

Figure 7. (a b c) Confocal Optical Perfilometry Laser LS-20x.
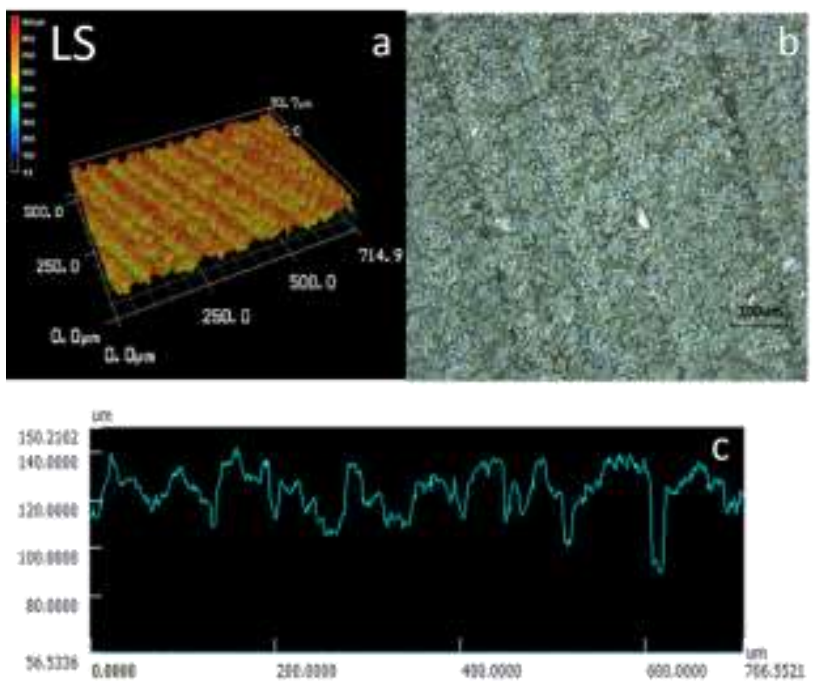

Source: Authors. 
Figure 8. (a b c) Confocal Optical Perfilometry Laser SS - 20x.
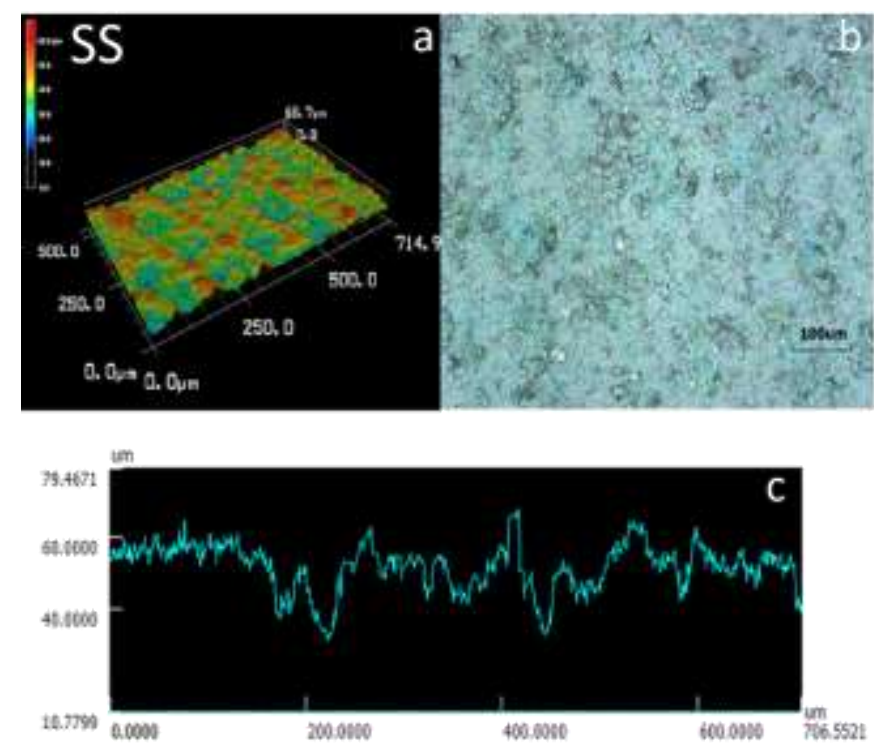

Source: Authors.

\section{Discussion}

In the beginnings of implantology, a period in which Branemark developed the first titanium implants, the surfaces were smooth, machined, without any type of surface treatment (Bränemark, et al., 1983). This type of surface used for decades has been the subject of several experimental (Souza, et al., 2013; Souza, et al., 2014) and clinical studies (Adell, et al., 1981). In a longitudinal study previously published (Adell, et al., 1981), the machined surface showed a success rate of $91 \%$ in implants installed in the mandible. However, in implants installed in the jaw, the success rate dropped to $81 \%$, which leads to the conclusion that the machined surface, in addition to being time dependent, has a low success rate in low-density bone. For this reason, the modification of the surface of dental implants has assumed great relevance in recent years.

Surface modification by laser beam was shown to be a promising method for treatment of implant surfaces because it is clean, reproducible and economically viable (Cho \& Jung, 2003; Sisti, et al., 2013). It is considered clean because it does not interact with external materials during the surface characterization process has a high degree of purity and roughness capable of promoting good osseointegration, and, furthermore there is no contamination of the oxide layer of titanium, since the technique does not use chemical elements (Filho, et al., 2011). The laser applied is of high intensity carried by optical fibers, which results in a greater homogeneity of this intensity on the surface of the implant. Between the lens system (focusing the laser beam on the sample diameter) and the sample, there is a device that has the function of protecting the lenses and preventing oxidation of the sample surface by creating an inert gas armature (Cho \& Jung, 2003). The laser presents the physicochemical properties of the formation of an oxygen-rich layer and the incorporation of nitrogen during the rapid melting and solidification of titanium (Gaggl, et al., 2000; Braga, et al., 2007; Faeda, et al., 2009; Queiroz, et al., 2013; Sisti, et al., 2013). The modification of the surface by laser beam leads to the formation of erosions on this surface, making it rough (Filho, et al., 2011). Cho and Jung (2003) compared machined implants with a laser-modified surface by means of topographic analysis (SEM) and reported that the laser-modified surface had regular cavities similar to those of a honeycomb, while the machined surface was relatively smooth and with typical machining signals.

Previous published studies employing these surfaces evaluated in this present work (machined surface, laser surface and laser surface with deposition of sodium silicate) evaluated their potential for new bone formation in implants placed in 
rabbit tibia and found higher removal torque values (Souza, et al., 2013) and bone implant contact, as well as neoformed bone area (Souza, et al., 2014) when compared to machined and acid-modified surfaces. Thus, the physico-chemical and morphological properties of the implant surface have a direct function in the osteogenesis, favoring the stages of the repair process in the interface formed between the bone and the implant (Queiroz, et al., 2017). In this present study when the surfaces were evaluated by SEM-EDX, LS and SS surfaces showed a complex morphology, and the presence of oxygen peaks, suggesting a physical-chemical modification of the surface. These physico-chemical modifications that the laser beam modification provides seem to favor the deposition of bone tissue.

The degree of bone implant contact seems to be influenced by the surface roughness of the implant (Gaggl, et al., 2000; Coelho, et al., 2009; Wennerberg \& Albrektsson, 2009). From the results obtained in the rugosimetry analysis, it was observed that the LS and SS groups had statistically larger mean roughness values $(\mathrm{p}<0.05)$ when compared to the MS Group. Previous published studies has related to the correlation of roughness values with removal torque values (Queiroz, et al., 2013; Souza, et al., 2013; Vercaigne, et al., 1998), bone implant contact and neoformed bone area (Souza, et al., 2014; Queiroz, et al., 2017).

The measurement of the contact angle of the drop of a liquid of interest on a given surface has been used to characterize its wettability (Queiroz, et al., 2013). The surface is considered hydrophobic when the contact angle is greater than $90^{\circ}$ and hydrophilic when the values are less than $90^{\circ}$. Hydrophilic surfaces allow a larger clot / implant contact due to their greater wettability (Elias, et al., 2008). In this present study it was observed that, although the mean value of the contact angle of the MS Group was less than $90^{\circ}$, that is, $74.3^{\circ}$, even though it was a high value when compared to the values found in LS and SS $\left(0^{\circ}\right)$. This fact indicates that MS does not present adequate wetting when compared to LS and SS that presents a wettability significantly superior to the MS. This greater wettability allows a better and more stable adhesion of the clot to the surface of the implant, favoring the deposition of bone tissue (Queiroz, et al., 2013).

Previous published study (Filho, et al., 2011) evaluated the titanium oxide formed compounds on laser-modified surfaces. The results obtained by the XRD suggested that the fusion and rapid solidification provoked by the irradiation of the laser (in normal atmosphere), induced the formation of titanium oxides, showing that the laser favored the propagation of oxygen atoms. One can also find the presence of nitrogen, according to the atmosphere. In this present study, it was verified that the machined surface showed only titanium peaks in the XRD analysis. In this present study the presence of oxides and nitrides was observed on the LS surface, due to the interaction with the air in the laser application process on the surface of the implant, and on the SS surface, silicate peaks were observed from the deposition of sodium silicate after modification by laser.

The surface-modifying laser beam's mechanism of action is based on the creation of a population of electrons encouraged to leave their natural state and enter a higher energy state. The electron population is created through the process of rapid fusion and solidification, which leads to a state of unbalance. When these electrons return to their natural state, the photons are emitted with an energy corresponding to the transition energy of the electron, leading to a physicochemical change on the surface (Gaggl, et al., 2000). The electron population may change due to creep. In other words, the electron population depends on creep, which is the relationship between density and area of energy (Silva, et al., 2016). The objective is create a homogeneous and controlled surface modification process, a fact observed in this present study at the SEM-EDX and XRD analysis. Also noteworthy is the high degree of wettability of the laser modified surface with or without sodium silicate coating as observed in the contact angle analysis.

Previous study published (Braga, et al., 2007) evaluated 9 parameters of the Nd: YV04 pulsed laser, analyzing the distribution of oxides and other compounds formed by cp-Ti surface irradiation through accumulated creep, pulse energy, repetition rate, and sweep rate. The results showed that the higher the creep, the higher the oxidation state of the titanium, that is, if the oxygen diffusion is high, the surface will retain a larger amount of oxygen, also showed that the creep of $280 \mathrm{~J} / \mathrm{cm}^{2}$ 
was not able. However another published study (del Pino, et al., 2002) demonstrated that fluencies above $294 \mathrm{~J} / \mathrm{cm}^{2}$ favor the formation of $\mathrm{TiO}$ and $\mathrm{Ti} 3 \mathrm{O}$ phases. The protocol applied in this present study was the pulsed $\mathrm{Yb}$ : 20W, with nominal power parameters of $140 \mathrm{~mJ}$ and pulse frequency of $20 \mathrm{KHz}$, in order to obtain rougher surfaces and formation of relevant oxidation phases as observed in SEM-EDX and XRD analyses.

Perfilometry analysis has been used to evaluate surface morphology, mean roughness values (Faverani, et al., 2014). It has the advantage of providing a three-dimensional reconstruction of the analyzed surface, enabling greater visibility of the analyzed surfaces. In this present study, the profile analysis showed that the LS and SS groups presented rough surfaces, with homogeneous pattern throughout the sample, when compared to the MS group, which presented smooth surface, presenting only grooves caused by the machining process.

The goal of sodium silicate incorporation was to make the laser-modified surface more bioactive. Previous published study (Souza, et al., 2013) showned that the presence of sodium silicate favors osseointegration by stabilizing the blood clot, attracting bone cells (osteoblasts) by chemotaxis, allowing bone neoformation. by osteoconduction. It is noteworthy that osseointegration is favored by the presence of titanium oxides and titanium nitrides, leading to a lower risk of implant loss. In this sense, the material properties, such as oxides and nitrites formed by laser irradiation, can promote increased corrosion resistance, surface wettability and greater hardness, favoring osseointegration (Filho, et al., 2011).

Currently, several methodologies have been studied related to different types of surface treatment, which, as well as in the present study, have obtained relevant success rates. Thus, it is considered extremely important to carry out in vitro and in vivo studies of modifications of implant surfaces in order to seek viable means that can accelerate the osseointegration process, increase the bone / implant interface and guarantee the initial stability of the implant. implant even in low quality bone, promoting a higher rate of success and longevity of the treatment.

\section{Conclusion}

In view of the results obtained, it was concluded that the surface texturizations performed in the LS and SS implants promoted important modifications in the topography and physical-chemical properties of the analyzed surfaces.

Taking into account the results obtained with this research, it is necessary to carry out an clinical study in humans to evaluate the biological responses to the surface changes used.

\section{Acknowledgments}

The authors would like to thank the Conexão Sistemas de Próteses for providing the implants and disks used in this study. The authors would like to São Paulo State Research Support Foundation - FAPESP - 2016/05264-4 and 2018/22108-1, CAPES-Print Project and Elton José de Souza from the São Paulo State University, School of Natural Sciences and Engineering, Ilha Solteira, Department of Phisycs and Chemistry for collaborating with SEM / EDX analysis and crosssectional analysis.

\section{References}

Adell, R., Lekholm, U., Rockler, B., \& Brånemark, P. I. (1981). A 15-year study of osseointegrated implants in the treatment of the edentulous jaw. International journal of oral surgery, 10(6), 387-416.

Albrektsson, T. \& Wennerberg, A. (2004). Oral Implant Surfaces: Part 1-Review Focusing on Topographic and Chemical Properties of Different Surfaces and in Vivo Responses to Them. The International journal of prosthodontics, 17(5), 536-543.

Braga, F. J. C., Marques, R. F. C., Almeida-Filho, E., \& Guastaldi, A. C. (2007). Surface modification of Ti dental implants by Nd:YVO4 laser irradiation. Applied Surface Science, 253, 9203-9208.

Bränemark, P. I., Adell, R., Albrektsson, T., Lekholm, U., Lundkvist, S., \& Rockler, B. (1983). Osseointegrated titanium fixtures in the treatment of edentulousness. Biomaterials, 4(1), 25-28. 
Carlsson, L., Rostlund, T., Albrektsson, B., \& Albrektsson, T. (1988). Removal torques for polished and rough titanium implants. The International journal of oral \& maxillofacial implants, 3(1), 21-24.

Cho, S. A. \& Jung, S. K. (2003). A removal torque of the laser-treated titanium implants in rabbit tibia. Biomaterials, 24(26), 4859-4863.

Coelho, P. G., Cardaropoli, G., Suzuki, M., \& Lemons, J. E. (2009). Early healing of nanothickness bioceramic coating on dental implants. an experimental study in dogs. Journal of biomedical materials research. Part B, Applied biomaterials, 88(2)B, 387-393.

del Pino, A. P., Serra, P., \& Morenza, J. L. (2002). Oxidation of titanium through Nd:YAG laser irradiation. Applied Surface Science, 197-198, 887-890.

Elias, C. N., Busquim, T., Lima, J. H. C., \& Muller, C. A. (2008). Caracterização e torque de remoção de implantes dentários com superfície bioativa. Revista brasileira de Odontologia, 65(2), 273-279.

Faeda, R. S., Tavares, H. A., Sartori, R., Guastaldi, A. C., \& Marcantônio-Jr, E. (2009). Biological performance of chemical hydroxyapatite coating associate with implant surface modification by laser beam: biomechanical study in rabbit tibias. Journal of oral and maxillofacial surgery, 67(8), 1706-1715.

Faeda, R. S., Tavares, H. S., Sartori, R., Guastaldi, A. C., \& Marcantônio-Jr, E. (2009). Evaluation of titanium implants with surface modification by laser beam. Biomechanical study in rabbit tibias. Brazilian oral research, 23(2), 137-143.

Faverani, L. P., Assunção, W. G., de Carvalho, P. S. P., Yuan, J. C. C., Sukotjo, C., Mathew, M. T., \& Barao, V. A. (2014). Effects of Dextrose and Lipopolysaccharide on the Corrosion Behavior of a Ti-6Al-4V Alloy with a Smooth Surface or Treated with Double-Acid-Etching. Plos One, 9, 1-15.

Filho, E. A., Fraga, A. F., Bini, R. A., \& Guastaldi, A. C. (2011). Bioactive coating on titanium implants modified by Nd:YVO4 laser. Applied Surface Science, 257, 4575-4580.

Gaggl, A., Schultes, G., Müller, W. D., \& Karcher, H. (2000). Scanning electron microscopical analysis of laser-treated titanium implant surfaces- a comparative study. Biomaterials, 21(10), 1067-1073.

Kesser-Liechti, G., Zix, J., \& Mericske-Stern, R. (2008). Stability measurements of 1-stage implants in the edentulous mandible by means of resonance frequency analysis. The International journal of oral \& maxillofacial implants, 23(2), 353-358.

Pereira, A. S., Shitsuka, D. M, Parreira, F. J. \& Shitsuka, R. (2018). Metodologia da pesquisa científica. [e-book]. Santa Maria. Ed. UAB / NTE / UFSM.

Qahash, M., Hardwick, R., Rohrer, M. D., Wozney, J. M., \& Wikesjö, U. M. (2007). Surface-etching enhances titanium implant osseointegration in newly formed (rhBMP-2-induced) and native bone. The International journal of oral \& maxillofacial implants, 22(3), $472-477$.

Queiroz, T. P., Souza, F. A., Guastaldi, A. C., Margonar, R., Garcia-Jr, I. R., \& Hochuli-Vieira, E. (2013). Commercially pure titanium implants with surfaces modified by laser beam with and without chemical deposition of apatite. Biomechanical and topographical analysis in rabbits. Clinical oral implants research, 24(8), 896-903.

Queiroz, T. P., de Molon, R. S., Souza, F. A., Margonar, R., Thomazini, A. H. A., Guastaldi, A. C., \& Vieira, E. H. (2017). In vivo evaluation of cp Ti implants with modified surfaces by laser beam with and without hydroxyapatite chemical deposition and without and with thermal treatment: topographic characterization and histomorphometric analysis in rabbits. Clinical oral investigations, 21, 685-699.

Shibli, J. A., Grassi, S., De Figueiredo, L. C., Feres, M., Marcantônio, E. Jr., Lezzi, G., \& Piattelli, A. (2007). Influence of implant surface topography on early osseointegration: a histological study in human jaws. Journal of biomedical materials research. Part B, Applied biomaterials, 80(2), 377-385.

Silva, F. L., Rodrigues, F., Pamato, S., \& Pereira, J. R. (2016). Tratamento de superfície em implantes dentários: uma revisão de literatura. RFO UPF, 21, 136142 .

Sisti, K. E., Piattelli, A., Guastaldi, A. C., Queiroz, T. P., \& De Rossi, R. (2013). Nondecalcified histologic study of bone response to titanium implants topographically modified by laser with and without hydroxyapatite coating. The International journal of periodontics \& restorative dentistry, 35(5), 689-696.

Souza, F. A., Queiroz, T. P., Guastaldi, A. C., Garcia-Jr, I. R., Magro-Filho, O., Nishioka, R. S., Sisti, K. E., \& Sonoda, C. K. (2013). Comparative in vivo study of commercially pure Ti implants with surfaces modified by laser with and without silicate deposition: biomechanical and scanning electron microscopy analysis. Journal of biomedical materials research. Part B, Applied biomaterials, 101(1), 76-84.

Souza, F. A., Queiroz, T. P., Sonoda, C. K., Okamoto, R., Margona, R., Guastaldi, A. C., Nishioka, R. S., \& Garcia Jr, I. R. (2014). Histometric analysis and topographic characterization of cp Ti implants with surfaces modified by laser with and without silica deposition. Journal of biomedical materials research. Part B, Applied biomaterials, 102, 1677-1688.

Thomas, K. \& Cook, S. D. (1992). Relationship between surface characteristics and the degree of bone-implant integration. Journal of biomedical materials research, 26(6), 831-833.

Vajtai, R., Beleznai, C., Nánai, L., Gingl, Z., \& George, T. F. (1996). Nonlinear aspects of laser-driven oxidation of metals. Applied Surface Science, 106, 247257.

Vercaigne, S., Wolke, J. G., Naert, I., \& Jansen, J. A. (1998). Bone healing capacity of titanium plasma-sprayed and hydroxyapatite-coated oral implants. Clinical oral implants research, 9(4), 261-271.

Wennerberg, A. \& Albrektsson, T. (2009). Structural influence from calcium phosphate coatings and its possible effect on enhanced bone integration. Acta odontologica Scandinavica, 67(6), 333-340.

Xavier, S. P., Carvalho, P. S. P., Beloti, M. M., \& Rosa, A. L. (2003). Response of rat bone marrow cells to commercially pure titanium submitted to different surface treatments. Journal of dentistry, 31(3), 173-180. 